\title{
A REVIEW OF IMPLEMENTATION OF HTML5 BASED PLATFORMS TO FACILITATE INTERACTIVE ONLINE LEARNING DURING COVID-19 PANDEMIC
}

\author{
Vikas Rao Naidu ${ }^{1 \star}$, Baldev Singh ${ }^{2}$, Aparna Agarwal ${ }^{3}$, Khadija Al Farei ${ }^{4}$, Khalid Al \\ Ismaily ${ }^{5}$, Raya Al Harrasi ${ }^{6}$, Nethra Vaidhyanathan ${ }^{7}$ \\ ${ }^{1}$ Dr., Middle East College, OMAN, vikasrn@gmail.com \\ 2Dr., Vivekananda Global University, INDIA, baldev.vit@gmail.com \\ ${ }^{3}$ Ms., Middle East College, OMAN, aparna@mec.edu.om \\ ${ }^{4}$ Ms., Middle East College, OMAN, kalfarei@mec.edu.om \\ ${ }^{5} \mathrm{Mr} .$, Middle East College, OMAN, kalismaily@mec.edu.om \\ ${ }^{6}$ Ms., Middle East College, OMAN, 10F6144@mec.edu.om \\ ${ }^{7}$ Ms., Middle East College, OMAN,17f17419@mec.edu.om \\ ${ }^{*}$ Corresponding Author
}

\begin{abstract}
In the world of eLearning, HTML5 is being hailed as the wave of the future. Since HTML5 is the new standard, eLearning professionals must get on board and begin using it to collaborate with other professionals and eLearning content developers. Businesses and educational institutions seeking online training will increasingly choose HTML5 courses over Flash because of the incredible compatibility opportunities and ease of authoring, which means they'll be searching for eLearning practitioners who are familiar with HTML5 resources. Because of its high degree of interactivity, immersive visuals, and engaging animations, Adobe Flash was once one of the most common authoring resources for eLearning courses. HTML5, a mobile-friendly option, is becoming the new choice among eLearning professionals as fewer smartphones and tablets will support Flash. However, the support for the Flash player has been discontinued by Adobe by the end of 2020, for most of the online platforms. And hence it is high time for the eLearning content developers and educators to think about the latest trends in education technology. Interactive Multimedia based authoring for eLearning will be very versatile if done using HTML5. This research paper reviews requirements and implementation of such eLearning tools for Online Teaching and Learning. This is especially needed in situations like the ongoing COVID-19 pandemic when most of the schools and higher education institutions have moved to adapt eLearning and online mode of teaching and learning.
\end{abstract}

Keywords: E-Learning, Online Learning, Education Technology, eLearning during COVID-19, Interactive Multimedia Authoring.

\section{INTRODUCTION}

The E-Learning industries are growing these days as the more and more interactive contents are being employed in teaching and learning. As compared to earlier days when e-learning was mainly accessible from desktops, the advent of mobile devices has drastically transformed the format of e-learning courses. Now-adays most of the users access e-learning materials mainly from their mobile devices. Thus, e-learning professionals have- to keep up with the newly changing demands of creating and delivering e-learning contents that are compatible for access from mobile devices. To fulfil these new challenges, e-learning professionals are using HTML5 eLearning authoring tools these days. HTML5 based tools are very much 
versatile offering a great range of features and options to the developers.

Main reason for shifting to HTML5 based authoring tools was a great surge in the usage of mobile devices in the recent years. Almost everyone owns a smartphone these days. Devices like iPhones, iPads, tablets and smartphones are commonly used by a large chunk of population. Moreover, these days the concept of "Bring Your Own Device (BYOD)" is increasing significantly. "BYOD Insights 2013" by a group of Cisco partner firms revealed in their report that every 9 in 10 people in USA uses smartphones for work purposes (BYOD Insights 2013 A Cisco Partner Network Study, n.d.).

In the earlier days the e-learning course contents were designed with the help of "Adobe Flash". But most of the mobile devices don't support Adobe flash and hence using such Flash-based e-learning programs became a challenge. The latest HTML5 based contents are supported on almost all the latest browsers and platforms. This has enabled the users to access the e-learning contents from any mobile devices. The content can also be stored, and data management can be done offline, eliminating the need for a continuous internet connectivity. Compared to Flash-based courser, these latest HTML5 based e-learning courses have a low CPU requirement and are faster with less battery consumption.

With the involvement of free and open source tools, it has become more feasible for educational institutions to adapt e-learning just merely by knowledge enhancements without investing a lot into hardware and specific upgrade in their infrastructure.(Naidu, Singh, et al., 2017)(Sharma \& Naidu, 2020) The learning analytics to measure students engagement in the class has led to further monitor the engagement in class activities of the students. With this the student's progress can be monitored through a well structured dashboard. (Rao Naidu et al., 2017)

\section{LITERATURE REVIEW}

In many of the educational institutes, E-Learning is being adopted on a wide scale an effective component for content delivery. To make it universally accepted, developing standards and principles for the same and making a systematic model to design it is needed. Different content developers or educational researchers have proposed varied models of e-learning based course designs. These models can be differentiated on the criteria of quality, but there exists a gap in each one of the models concerning the expectations of the teachers and learners, the designs of the content developers and the requirements of the system developers. The researchers in this paper by Saeed et al., have proposed a design for the e-learning courses to conduit the gaps identified in the previous models. The model proposed by the researchers is based on the analysis done for the identified models. They have designed and developed the model for the e-learning course and stated its applications. Further, the model has been evaluated for the performance criteria and the usability of the model in different educational set-ups. For the purpose of analyzing this model, a case study had been developed at the different stages, the platform used was Moodle. The case study illustrates the process of creating the courses, study plans, content for every semester etc. The scientific content created was designed on the basis of the educational approaches implemented by the universities in Iraq. Their findings suggest that the proposed model was successful and got positive reviews from the learners, educators and the content designers. This was particularly more acceptable in the Arab and Iraq learning environments. The proposed model's success depends on the fact that it addresses the gaps identified in the previous models by the authors and is also easy to use. It is general, systematic and standardized. A good content design will ensure the student involvement and will retain their interest in the elearning set-up. As for the educators, it is easy to use and it will motivate them to stick to e-learning environments rather than the traditional set-ups. (Saeed)

Synytsya et al., in their research have described the different categories of assessment tasks that can be used for e-learning set-ups. They have also studied the use of HTML5 for the development of interactive content for the e-learning environment. The most common practices for the development of designs related to the user interfaces have been examined. They have also supported their findings with examples from different e-learning environments. The authors have appreciated the features offered by HTML5 and considered it as a powerful tool for the web content developers. This technology can augment the experience of any general web browser, any game-based learning environment or any e-learning system. The design of the assessments need some controls that are easy to design using HTML5 features. Its features are a guarantee that interactions implemented in the content will be compatible with almost all the mobile platforms. Thus e-learning will be having one of its branches as mobile learning.

The paper authored by Daoust et al., is highly driven by the fact that the media industry is being revolutionized by the latest trends related to video accesses and sharing. They are exploring the imminent of internet video in their paper. They have discussed the HTML5 as a new standard of web content creation. 
They have highlighted the unified content creation using HTML5, the ease of using it, platform independence feature, and a latest innovative technique of adaptive video coding. They have further analyzed the use of these above-mentioned techniques and their benefits over the old-fashioned client server model and also the innovative P2P centered distribution models. They have concluded their study with an elaborate discussion on the difficulties that lay in the path of making videos real natives of the web world. The use of web technologies can help create ironic user interfaces that are based on HTML5, provide a control to functionalities of the device by giving access to the API of the device being used to create the content based on the user preferences, and his/her social and physical set-up. The HTTP streaming would be appearing in the format of a play-list and will be platform independent. This format will help in reaching out to the global users but might need the support of media fragments URIs. The peer-to-peer interaction that is needed for collaborative learning requires video conferencing and HTTP based solutions will be sufficient to support them in a secured environment. Gaming on the web platform can be enhanced using advanced graphic rendering using WebGL specification.

Reyna, in his article has discussed the increasing sophistication of the web designs, state-of-the-art browser techniques, and the web design principles that includes the fluid grids, media queries, malleable images etc. All this helps the users to get an eminent experience irrespective of the devices that they are having i.e., the size of the display unit is small or large. He has also pointed out that it requires a knowledge and expertise on the various screen design strategies to make a modernized web design that can target a varied range of audiences on an extensive collection of electronic devices. These inclinations in the digital background bargain a drive for e-learning specialists to train in these state-of-the-art technologies. The areas that will be initiating the changes are HTML5, CSS3, JQuery, Media Queries and JavaScript. A novel approach which is like a proactive initiative will aid in meeting the challenges of the recent technologies. He has discussed about the how these technologies are shaping the content of the e-learning environment. He has highlighted the positives of the two new concepts being used in the recent web designs: responsive design and progressive enhancement as an essential ingredient. They have also taken reviews from different articles which show that the tablets are becoming an integrated part of the e-learning especially in higher education, which has led to an increase in the learners' engagement and enhancing their learning experiences.

The implementation of these e-learning solutions must be hosted on cloud to enable the global access by students at any point of time. (Naidu et al., 2019) Cloud hosting has some other important advantage such as automated and scheduled backup of content, access to learning analytics by the teachers etc.

\subsection{HTML5 - the Future of Educational Content Authoring}

All these years "Flash" software had been the standard tool for designing e-learning courses. But the trend is changing these days as most of the professional designers are implementing HTML5 as the latest standard authoring tool.

Here are few reasons behind this change in the trend towards HTML5

\subsection{1 "Mobile-Friendliness"}

The prevailing trend these days is any regular learner prefers to use their mobile devices for accessing the elearning material. Although 'Flash' has offered great animations, graphics and interactivity, still it has a main demerit as most of the modern smartphones don't support 'Flash-based' contents. In such cases HTML5 has emerged as the latest favourite among professionals mainly because it lets the e-learning contents to adjust itself as per the screen-size of the mobile devices. The developers can also create 'smart meta-tags' for optimizing their e-learning content for mobile devices (Malhotra, 2019).

\subsection{2 "Better Accessibility"}

As working people are getting busier by the days, they hardly have time to dedicate in front of laptops or desktops for e-learning. Modern learner wants a flexibility to access these e-learning contents whenever wherever they wish. Such flexibility has been made possible thanks to HTML5. What is even best part of HTML5, is the learners can download and store e-learning contents in offline storage and hence access it anywhere anytime even without any connectivity to internet (Malhotra, 2019).

\subsection{3 "Easy Customizability"}

HTML5 being a markup language, offers great flexibility for in-depth customization of every detail. Unlike 'Flash', there are no limitations to accessibility with HTML5 and content can adjust to fit various screen-size and browsers. Another advantage with HTML5 is different modifications can be done just be changing the coding and doesn't require any additional software or plug-ins. The HTML5 based contents and apps can 
work on all the online platforms and browsers and there are no operating system requirement issues (Malhotra, 2019).

\subsection{4 "Latest Standard"}

HTML5 has become the 'Latest standard' for creating e-learning contents and professional around the globe have already stated using it for this purpose. For those who want to keep up with the pace and design contents keeping future in mind, then HTML5 is the best choice (Malhotra, 2019).

The process of converting existing 'Flash-based' e-learning contents into HTML5 might seem a laborious task but today there are many companies who offer this conversion. One such company is "CBLPro" helps in this conversion. When conversion is outsourced to such professional companies, they can offer a better result (Malhotra, 2019).

\section{H5P}

It's a free and open-source cloud-based tool that allows the user to create HTML5 e-Learning content and publish it on famous platforms like WordPress, Drupal and Moodle (H5P - Create and Share Rich HTML5 Content and Applications, 2019). Here it's important not to confuse ' $h 5 p . o r g$ ' and ' $h 5 p . c o m$ '. The ' $h 5 p . o r g$ ' is free for trial purpose while the 'h5p.com' is a paid service. So if user wants a free eLearning authoring tool, he must visit to h5p.org (6 Best Authoring Tools for ELearning - Atomi Systems, Inc., 2019).

\subsection{1 "Its Pros"}

- H5P lets the user to create, share, modify or reuse interactive HTML5 on an online cloud-based platform

- User need to create an account in h5p.org, after which they can start developing online e-learning content such as videos, quizzes, course presentations, simple games and flashcards

- It's a great tool for group collaboration and offers around 40 different interactive activities. The main advantage of this tool is its free and easy to use (6 Best Authoring Tools for ELearning - Atomi Systems, Inc., 2019).

- The user doesn't need any specific technical skill to use this tool.

- Mobile friendly content may be created using H5P, thus users can experience the same rich, interactive content alike on computers, smartphones and tablets (H5P - Create and Share Rich HTML5 Content and Applications, 2019).

- By using the open API the developers can create new H5P content types (Top 7 Free ELearning Authoring Tools - Take Your Pick, 2020).

\subsection{2 "Its Cons"}

- The tool can't run standalone and needs to be used as a plugin to WordPress, Drupal or Moodle.

- It doesn't support importing PowerPoint presentations.

- For designing complex and customized eLearning projects there are very limited options.

- There is no Screen or webcam recording features.

- All the projects made on H5P.org will be visible to public and there is no option to make contents private in it (6 Best Authoring Tools for E-Learning - Atomi Systems, Inc., 2019).

- There is no option to preview.

- The content is compatible only with LMSs supporting LTI integration (Top 7 Free E-Learning Authoring Tools - Take Your Pick, 2020).

\subsubsection{Pricing and plans}

H5P.org is a free and open-source tool.

\section{REVIEW OF HTML BASED EDUCATIONAL TOOLS}

HTML5 is the current standard language for organizing and delivering web content. HTML5 was created with the goal of better handling the latest multimedia formats when it first appeared on the scene. Authoring e- 
learning in HTML5 has numerous advantages are compared in Table 1, for some of the important tools other than H5P. (Mehrotra, 2019)(Maloney, 2020)

\begin{tabular}{|c|c|c|c|}
\hline & $\begin{array}{l}\text { Tool } \\
\text { Name }\end{array}$ & Great For & Drawback \\
\hline 1 & Elucidat & $\begin{array}{l}\text { - Creating learning experiences that } \\
\text { are interesting, interactive, and } \\
\text { individualized. } \\
\text { - Ensuring that learning content is } \\
\text { mobile-friendly and compatible with } \\
\text { all devices. } \\
\text { - Expanding your audience by } \\
\text { managing translated content and } \\
\text { course versions intelligently, as well } \\
\text { as delivering content to people } \\
\text { outside of your LMS. } \\
\text { - Using built-in blueprints to speed up } \\
\text { production processes, allowing any } \\
\text { user to instantly create exceptional } \\
\text { e-learning. }\end{array}$ & $\begin{array}{l}\text { Elucidat is best suited for organizations } \\
\text { who need to support thousands of } \\
\text { individuals with e-learning. The platform is } \\
\text { built to provide a high return on investment } \\
\text { for teams that produce content at a large } \\
\text { scale. However, if you're a small team or a } \\
\text { single person wanting to build a few } \\
\text { hundred courses, Elucidat's platform is } \\
\text { unlikely to be the ideal option for you. }\end{array}$ \\
\hline 2 & $\begin{array}{l}\text { Adobe } \\
\text { Captivate }\end{array}$ & $\begin{array}{l}\text { - } \text { Creating intricate interactions. } \\
\text { - You can edit screen recordings and } \\
\text { simulations within the tool. } \\
\text { - Any interactions that are location- } \\
\text { aware (you can use a device's } \\
\text { geographic functionality). } \\
\text { - The output's interactivity may able } \\
\text { to assume mobile device gestures } \\
\text { (e.g, pinch and zoom, swipe). } \\
\text { - Types of interactions based on } \\
\text { accelerometers. }\end{array}$ & $\begin{array}{l}\text { - Learning curve is steep, and there isn't } \\
\text { much help. } \\
\text { - When it comes to evaluating and } \\
\text { generating content, you can't simply } \\
\text { collaborate with a desktop-based } \\
\text { solution. } \\
\text { - Though you can observe different } \\
\text { screen sizes, authoring decisions } \\
\text { cannot be made per device. } \\
\text { Furthermore, because high-leve } \\
\text { features are Flash-based, not all } \\
\text { elements would work on mobile } \\
\text { devices. } \\
\text { Updating and maintaining current } \\
\text { information can be a time-consuming } \\
\text { procedure. }\end{array}$ \\
\hline 3 & $\begin{array}{l}\text { Articulate } \\
\text { Storyline } \\
360\end{array}$ & $\begin{array}{l}\text { - Some external multimedia content } \\
\text { can be imported (like Power points } \\
\text { and PDFs). } \\
\text { - The content has been designed to } \\
\text { be seen on a desktop computer. } \\
\text { - Pages with themes and branding } \\
\text { that may be applied in a variety of } \\
\text { ways. } \\
\text { - If you have the skills, you can } \\
\text { customize the code. } \\
\text { - In terms of content output, there is a } \\
\text { lot of flexibility and control. }\end{array}$ & $\begin{array}{l}\text { Creating a brand that is consistent } \\
\text { across multiple authors (and so } \\
\text { downloads). } \\
\text { - Because assets are not stored } \\
\text { centrally, authoring can be slowed. } \\
\text { - Collaboration and content changes } \\
\text { might take a lot of time. } \\
\text { - It isn't fully mobile responsive; instead, } \\
\text { the screen is shrunk. } \\
\text { - Because it's a desktop application, you } \\
\text { won't get new features or bug patches } \\
\text { right away. }\end{array}$ \\
\hline
\end{tabular}




\begin{tabular}{|c|c|c|c|}
\hline & & $\begin{array}{l}\text { Because it's such a prevalent tool, } \\
\text { designers are more likely to be } \\
\text { familiar with it. } \\
\text { - Online community with a lot of } \\
\text { activity. } \\
\text { - Simulator software for testing that is } \\
\text { reasonably powerful. }\end{array}$ & $\begin{array}{l}\text { - If you have a large number of authors, } \\
\text { it might be quite costly. }\end{array}$ \\
\hline 4 & Gomo & $\begin{array}{l}\text { - Using Youtube, Google Maps, and } \\
\text { Twitter feeds to import web } \\
\text { material. } \\
\text { - Content can be hosted online or } \\
\text { offline using the Gomo app. } \\
\text { - It provides a drag-and-drop } \\
\text { interface for authors with no coding } \\
\text { skills. } \\
\text { Creating mobile-friendly, responsive } \\
\text { content. }\end{array}$ & $\begin{array}{l}\text { - It's not the most user-friendly interface, } \\
\text { and you can't see your changes in real } \\
\text { time because it's not a 'What You See } \\
\text { Is What You Get' interface. } \\
\text { - Because interactive templates are set } \\
\text { up in a two-column framework, design } \\
\text { flexibility is limited. } \\
\text { - For imaginative images, customization } \\
\text { options may not be sufficient. }\end{array}$ \\
\hline 5 & Lectora & $\begin{array}{l}\text { - Image editing or screen recording } \\
\text { - } \quad \text { Interaction flexibility. } \\
\text { Review Link has capabilities for } \\
\text { reviewing and commenting (only for } \\
\text { Online edition of this tool). } \\
\text { - Obtaining free access to the } \\
\text { graphics library of Elearning } \\
\text { Brothers. }\end{array}$ & $\begin{array}{l}\text { - Although Lectora has outputs for both } \\
\text { mobile and desktop viewing, you must } \\
\text { choose which one you want to design } \\
\text { in from the start. } \\
\text { - A good (third-party) graphics program } \\
\text { may be required to change aspects via } \\
\text { the developer interface. } \\
\text { - Learning curve is steep, and there isn't } \\
\text { much help. } \\
\text { The user interface is not very user- } \\
\text { friendly. } \\
\text { Delivering content to different devices } \\
\text { presents a number of challenges. }\end{array}$ \\
\hline 6 & $\begin{array}{l}\text { Adapt } \\
\text { Learning }\end{array}$ & $\begin{array}{l}\text { - It's free for those on a tight budget. } \\
\text { - You can build custom } \\
\text { interactions/layouts, etc. using the } \\
\text { (free) framework rather than the tool } \\
\text { if you're a developer or have access } \\
\text { to one. } \\
\text { - Changing the look and feel of the } \\
\text { interface. } \\
\text { - Creating content that is totally } \\
\text { responsive and available on any } \\
\text { device. }\end{array}$ & $\begin{array}{l}\text { - Design limitations (because to the } \\
\text { "blocky" layout, most Adapt courses } \\
\text { will seem the similar). } \\
\text { - The heavily coded background and } \\
\text { guidelines can cause a lengthy and } \\
\text { slow download procedure. } \\
\text { - A small number of interactions } \\
\text { - Not cloud-based, therefore installation } \\
\text { can take a long time. }\end{array}$ \\
\hline 7 & $\begin{array}{l}\text { Easygene } \\
\text { rator }\end{array}$ & $\begin{array}{l}\text { - Authors who are just getting started } \\
\text { with elearning material creation - no } \\
\text { coding required! } \\
\text { - The 'Next-Gen Authoring' function } \\
\text { was used to create a mobile-friendly }\end{array}$ & $\begin{array}{l}\text { - Limited functionality - but the staff is } \\
\text { prepared to listen to suggestions and } \\
\text { deliver updates based on the needs of } \\
\text { clients. }\end{array}$ \\
\hline
\end{tabular}




\begin{tabular}{|c|c|c|c|}
\hline & & $\begin{array}{l}\text { responsive design. } \\
\text { SCORM and Tin-Can compatibly } \\
\text { content, ensuring interoperability } \\
\text { with the vast majority of LMSs. }\end{array}$ & $\begin{array}{l}\text { is fully adapted for different devices. } \\
\text { - Certain price plans include limitations } \\
\text { on the kind of questions/quizzes that } \\
\text { can be asked. } \\
\text { - Many of the long-form questions have } \\
\text { a word limit. }\end{array}$ \\
\hline 8 & $\begin{array}{l}\text { iSpring } \\
\text { Suite }\end{array}$ & $\begin{array}{l}\text { Developing mobile-friendly courses } \\
\text { that include simulations, video, and } \\
\text { a variety of exams. } \\
\text { - Use voiceover or synchronized } \\
\text { sound to create video lectures. } \\
\text { - It's the Content Library, which gives } \\
\text { authors access to templates, course } \\
\text { media such as images and } \\
\text { backgrounds, and themes. } \\
\text { Recording a screencast. }\end{array}$ & $\begin{array}{l}\text { - The whole range of tools can be } \\
\text { intimidating, as each of these } \\
\text { functions is available as a separate } \\
\text { product or package. } \\
\text { - Price barriers prevent some functions } \\
\text { and add-ons from being used. }\end{array}$ \\
\hline
\end{tabular}

Table. 1: Comparison of e-Learning Tools based on HTML5

\section{REVIEW OF H5P IMPLEMENTATION IN ONE OF THE HEI IN OMAN DURING COVID19 PANDEMIC}

COVID -19 pandemic circumstances led to the acceptance of online learning on a wide scale. As the educational institutes moved to off campus teaching and new strategies were being worked out for realizing the same, Middle East College in Muscat, Oman adopted the H5P technology as an integrated plugin with the Learning management System, MEC Learn. This aided in making the learning material for the learners at MEC, which utilized multimedia to create interactive content. The learning content created with H5P was easy to be developed, to use and to reuse. The activity of the students on a H5P package can be easily tracked in the gradebook. The amount of time spent on the package, the grades obtained in the off-class and in-class activities helped in tracing the involvement of the students. Also, this served to motivate the students to be active as they know that their activity and involvement is being quantified and tracked. The pre class, in-class and post class activity schedule in the package helped the students to prepare themselves well for the active discussion during the online class and assess themselves with the post class activity. So, the students are not only being driven for self-leaning but are also learning to assess themselves and put more efforts on the areas of concern in the curriculum. Students were also appreciative of the learning material prepared using $\mathrm{H} 5 \mathrm{P}$.

\section{CONCLUSION}

The authors have covered a lot of territory in this article, and you've probably noticed that the roles of the tools discussed overlap quite a bit. However, each tool has certain essential variations and peculiarities that will suit every type of authoring team. The authoring process of interactive content requires a proper planning of content. Not only planning, but also knowledge of Human Computer interaction principles for e-learning content design is also important, which defines certain standards for enhanced engagement. (Naidu, Srinivas, et al., 2020)(Al Mahdi et al., 2019)

Game based learning experience is another important aspect of HTML5 which further enhances classroom engagement, especially for brainstorming and revision sessions. (Naidu, Al Balushi, et al., 2017) Other emerging trends in education technology includes, implementation of machine learning algorithms along with learning management systems to study student's progress and perform predictions based on which the further results could be drawn, usage of social media especially during online education in Pandemic, different data mining techniques for educational data and emerging trends of big data in higher education to enhance teaching and learning experience. (Agarwal et al., 2021)(Agarwal et al., 2019) (Al Mamari et al., 2019)(Hasan et al., 2020)(Poloju \& Naidu, 2020)(Mohammed et al., 2019)(Mohammed et al., 2020)(Naidu, Singh, et al., 2020)

Overall, picking an HTML5 authoring tool sounds like the appropriate decision for you if you're thinking about 
emphasizing mobile-friendly e-learning content in the coming year, or even if you just want to experiment with more interactions to increase engagement. However, based upon the implementation of H5P on Moodle, it was found to be more technically feasible, cost effective and user friendly for students as well.

\section{ACKNOWLEDGEMENT}

The authors would like to thank the management and staff of Middle East College Oman for their encouragement in this research.

\section{REFERENCE LIST}

6 Best Authoring Tools for eLearning - Atomi Systems, Inc. (2019). https://atomisystems.com/elearning/6best-authoring-tools-for-elearning/

BYOD Insights 2013 A Cisco Partner Network Study. (n.d.). Retrieved September 15, 2017, from https://www.varinsights.com/doc/byod-insights-a-cisco-partner-network-study-0001

H5P - Create and Share Rich HTML5 Content and Applications. (2019). https://h5p.org/

Top 7 Free eLearning Authoring Tools - Take Your Pick. (2020). https://www.ispringsolutions.com/blog/freeelearning-authoring-tools

Daoust, François \& Hoschka, Philipp \& Patrikakis, Charalampos \& Santos Cruz, Rui \& Nunes, Mario \& Osborne, David. (2010). Towards Video on the Web with HTML5.

Reyna, Jorge. (2012). From Flash to HTML5: The E-learning Evolution. Training \& Development Magazine. Vol 37.

Saeed, Mustafa \& Malallah, Fahad \& Alasaady, Maher. (2019). A proposed model for designing E-learning courses. Journal of Theoretical and Applied Information Technology. 97. 1239 -1250.

Synytsya, Kateryna \& Prokofyeva, Natalya \& Grocevs, Aleksejs \& Tomko, Vladimirs. (2014). HTML5 in Development of Assessment Tasks for e-Learning. Applied Computer Systems. 16. 10.1515/acss-20140020.

Agarwal, A., Naidu, V. R., \& Al Mamari, R. (2019). a Framework To Enhance Learning Experience in Flipped Classroom Based on Student Accountability Towards Active Participation. EDULEARN19 Proceedings, 1(July), 1569-1577. https://doi.org/10.21125/edulearn.2019.0464

Agarwal, A., Saqib, M., Hasan, R., Srinivas, S., Rao Naidu, V., \& Jesrani, K. (2021). Educational Association Mining on the Use of Media Platforms for e-Learning. 2021 2nd International Conference on Computation, Automation and Knowledge Management (ICCAKM). https://doi.org/10.1109/ICCAKM50778.2021.9357727

Al Mahdi, Z., Rao Naidu, V., \& Kurian, P. (2019). Analyzing the Role of Human Computer Interaction Principles for E-Learning Solution Design (pp. 41-44). Springer, Cham. https://doi.org/10.1007/978-3030-01659-3_6

Al Mamari, R., Naidu, V. R., \& Agarwal, A. (2019). A PROPOSED FRAMEWORK FOR EFFECTIVE USAGE OF SOCIAL MEDIA IN HIGHER EDUCATION ESTABLISHMENTS. EDULEARN19 Proceedings, 1, 7337-7341. https://doi.org/10.21125/edulearn.2019.1755

Hasan, R., Palaniappan, S., Mahmood, S., Naidu, V. R., Agarwal, A., Singh, B., Sarker, K. U., Abbas, A., \& Sattar, M. U. (2020). A Review: Emerging Trends of Big Data in Higher Educational Institutions (pp. 289-297). Springer, Singapore. https://doi.org/10.1007/978-981-15-2329-8_29

Malhotra, M. (2019). Why HTML5 Is The Future Of eLearning - eLearning Industry. https://elearningindustry.com/future-of-elearning-html5

Maloney, K. (2020). HTML5 elearning authoring tools - a comparison I Elucidat. Educidat. https://www.elucidat.com/blog/html5-authoring-tools/

Mehrotra, M. (2019). Why HTML5 Is The Future Of eLearning - eLearning Industry. ELearning Industry. https://elearningindustry.com/future-of-elearning-html5 
Mohammed, Q. A., Naidu, V. R., Hasan, R., Mustafa, M., \& Jesrani, K. A. (2019). DIGITAL EDUCATION USING FREE AND OPEN SOURCE TOOLS TO ENHANCE COLLABORATIVE LEARNING. IJAEDUInternational E-Journal of Advances in Education, 13, 50-57. https://doi.org/10.18768/ijaedu.531636

Mohammed, Q. A., Rao Naidu, V., Said, M., Al Harthi, A., Babiker, S., Al Balushi, Q., Yousuf, M., Rawahi, A., Harib, N., \& Al Riyami, S. (2020). ROLE OF ONLINE COLLABORATIVE PLATFORM IN HIGHER EDUCATION CONTEXT. In IJAEDU-International E-Journal of Advances in Education: Vol. VI (Issue 17). https://doi.org/10.18768/IJAEDU.789422

Naidu, V. R., Al Balushi, H., \& Bhatia, S. (2017). Effectiveness of Free \& Open Source Tools To Enhance Game Based Learning Experience in School Education. EDULEARN17 Proceedings, 1(July), 66046609. https://doi.org/10.21125/edulearn.2017.2505

Naidu, V. R., Bhat, A. Z., \& Singh, B. (2019). Cloud Concept for Implementing Multimedia Based Learning in Higher Education (pp. 81-84). Springer, Cham. https://doi.org/10.1007/978-3-030-01659-3_11

Naidu, V. R., Singh, B., Al Harrasi, R. A., \& Al Balushi, H. H. (2017). TECHNOLOGY ENHANCED LEARNING ASSISTED BY FREE AND OPEN SOURCE SOFTWARE. IJAEDU- International E-Journal of Advances in Education. https://doi.org/10.18768/ijaedu.338515

Naidu, V. R., Singh, B., Farei, K. Al, \& Suqri, N. Al. (2020). Machine Learning for Flipped Teaching in Higher Education-A Reflection (pp. 129-132). Springer, Cham. https://doi.org/10.1007/978-3-030-329020_16

Naidu, V. R., Srinivas, S., Al Raisi, M., \& Dattana, V. (2020). Evaluation of Hypermedia Tools in Terms of Usability Heuristics for English Language Teaching. Arab World English Journal (AWEJ), 133-149.

Poloju, K. K., \& Naidu, V. R. (2020). Impact of E-tools in Teaching and Learning for Undergraduate Students. In H. S. Saini, R. K. Singh, M. Tariq Beg, \& J. S. Sahambi (Eds.), Innovations in Electronics and Communication Engineering (pp. 783-790). Springer Singapore.

Rao Naidu, V., Singh, B., Hasan, R., \& Al Hadrami, G. (2017). LEARNING ANALYTICS FOR SMART CLASSROOMS IN HIGHER EDUCATION. In IJAEDU-International E-Journal of Advances in Education (Vol. 3). http://ijaedu.ocerintjournals.org

Sharma, A., \& Naidu, V. R. (2020). a Study on Emerging Trends To Enhance Learning Experience in Higher Education Institutions. INTED2020 Proceedings, 1(March), 7391-7396.

https://doi.org/10.21125/inted.2020.1974 